\title{
COVID-19 and neuromuscular disorders
}

Amanda C. Guidon, MD, and Anthony A. Amato, MD

Neurolog ${ }^{\circledR}$ 2020;94:959-969. doi:10.1212/WNL.0000000000009566

\section{Abstract}

The coronavirus 2019 (COVID-19) pandemic has potential to disproportionately and severely affect patients with neuromuscular disorders. In a short period of time, it has already caused reorganization of neuromuscular clinical care delivery and education, which will likely have lasting effects on the field. This article reviews (1) potential neuromuscular complications of COVID-19, (2) assessment and mitigation of COVID-19-related risk for patients with preexisting neuromuscular disease, (3) guidance for management of immunosuppressive and immunomodulatory therapies, (4) practical guidance regarding neuromuscular care delivery, telemedicine, and education, and (5) effect on neuromuscular research. We outline key unanswered clinical questions and highlight the need for team-based and interspecialty collaboration. Primary goals of clinical research during this time are to develop evidence-based best practices and to minimize morbidity and mortality related to COVID-19 for patients with neuromuscular disorders.

\section{Introduction}

Whereas several human coronaviruses, including hCoV-229E, OC43, NL63, and HKU1, are associated with mild respiratory symptoms, more severe coronavirus infections have appeared over the last 2 decades. These newer coronavirus infections can result in severe acute respiratory syndrome (SARS) and include Middle East respiratory syndrome (MERS) and most recently coronavirus disease 2019 (COVID-19). These severe coronavirus infections have been associated with headache, seizures, and stroke, but literature regarding neuromuscular complications is scant. It is possible that associated neuromuscular disorders (NMDs) have occurred previously but have been overshadowed by systemic manifestations.

During the current COVID-19 pandemic, we need to be vigilant for neuromuscular complications that may be directly or indirectly related to coronavirus infection (table 1). We should also plan to adjust our clinical practices to prevent the spread of COVID-19 and to care for patients with NMDs and the complications they experience during this time. Finally, since the effects of the pandemic are expected to persist for longer than several weeks, we will want to adapt neuromuscular educational training programs. This article reviews the current state of knowledge and practice in these 3 areas, provides guidance, and raises clinical questions for future investigation.

\section{Assessment of overall risk from COVID-19 in patients with NMD}

Our current discussions with patients center upon risk and risk mitigation. Risks will depend upon the specific NMD, other comorbidities, age, and what immunotherapies the patients may be receiving (table 2). We do not expect the majority of patients, even in the higher risk categories, to have severe complications of COVID-19. We also can reassure patients that NMDs that spare swallowing and breathing muscles and where treatment does not involve immunosuppression are

\section{Correspondence}

Dr. Guidon

aguidon@partners.org

or Dr. Amato

aamato@bwh.harvard.edu

MORE ONLINE

\section{COVID-19 Resources}

For the latest articles, invited commentaries, and blogs from physicians around the world

NPub.org/COVID 19

From the Division of Neuromuscular Medicine, Department of Neurology, Massachusetts General Hospital (A.C.G.), and Division of Neuromuscular Medicine, Department of Neurology, Brigham and Woman's Hospital (A.A.A.), Harvard Medical School, Boston, MA.

Go to Neurology.org/N for full disclosures. Funding information and disclosures deemed relevant by the authors, if any, are provided at the end of the article. 


\section{Glossary}

AANEM = American Academy of Neuromuscular and Electrodiagnostic Medicine; ALS = amyotrophic lateral sclerosis; CK = creatine kinase; COVID-19 = coronavirus disease 2019; FcRn = neonatal Fc receptor; FDA = Food and Drug Administration; GBS = Guillain-Barré syndrome; IST = immunosuppressive therapy; MERS = Middle East respiratory syndrome; MG = myasthenia gravis; NMD = neuromuscular disorder; SARS = severe acute respiratory syndrome; SARS-CoV-2 = severe acute respiratory syndrome coronavirus 2 .

not considered to be high risk in COVID-19. On the other hand, patients may be in an overall higher-risk category due to other demographic factors or health considerations. At this time, the primary advice for all patients and their caregivers is to reduce the risk of contracting the virus through social distancing, handwashing, and stricter isolation in patients who are most at risk. Internationally, neurologic (International MG/ COVID Working Group), rheumatologic (COVID-19 Global Rheumatology Alliance), and gastroenterologic (Surveillance Epidemiology of Coronavirus [COVID-19] Under Research Exclusion [SECURE-IBD]) groups have begun to publish consensus guidance statements to address clinical care and risk mitigation during COVID-19 for specific patient populations, with plans for updates as outcomes data become available.

\section{Risk of infection causing a new NMD}

There is a known risk of Guillain-Barré syndrome (GBS) attributable to viral infections (e.g., influenza, H1N1, Zika, Epstein-Barr virus). The rationale is that molecular mimicry exists between specific viral proteins and proteins on peripheral nerves (e.g., gangliosides) leading to an innocent bystander attack against the myelin or axon of peripheral nerves. There is 1 reported case of GBS in association with COVID-19; however, direct causality is uncertain. ${ }^{1}$ GBS has been reported rarely with other coronavirus infections. ${ }^{2,3}$

There is no current evidence of direct viral invasion with inflammation and degeneration of motor neurons and peripheral nerves as seen in some viral infections (e.g., poliovirus, enterovirus D68, West Nile, herpes zoster, cytomegalovirus). In the literature, there is 1 report of a 3-year-old child with acute flaccid paralysis who was coinfected with 2 coronaviruses ( HCoV 229E and OC43). ${ }^{4}$ However, the diagnosis was questionable; the child had normal EMG and nerve conduction studies 1 and 3 weeks after onset, normal CSF, and normal brain and spinal cord MRI. Nevertheless, it is possible that the virus may be neurotropic and directly infect and damage motor neurons and peripheral nerves.

Coronavirus infections may be associated with myopathies. In recently published studies of COVID-19 in China, myalgia or fatigue affected $44 \%-70 \%$ of hospitalized patients and increased creatine kinase (CK) was present in up to $33 \%$ of admitted patients. ${ }^{5,6}$ No additional workup such as EMG, muscle imaging, or histopathology was reported. Likewise, as many as a third of patients infected with other coronavirus infections manifested with myalgias and elevated $\mathrm{CKs}^{7,8}$ and rhabdomyolysis. ${ }^{9,10}$ This suggests that coronavirus infections may cause a viral myositis. Very sick patients with coronavirus develop critical illness myopathy or polyneuropathy. ${ }^{10-13} \mathrm{~A}$ risk factor for developing critical illness myopathy is use of nondepolarizing neuromuscular blocking agents. Nevertheless, this has not been reported in patients with other coronavirus receiving short courses of these medications. ${ }^{14}$ Weakness related to type 2 muscle fiber atrophy from disuse typically presents after 1 week in ill patients who are bedridden and therefore will be a consideration in patients with COVID-19.

\section{Risk of COVID-19 infection exacerbating known or unmasking previously unrecognized NMDs}

There are no data regarding magnitude of risk of exacerbation due to COVID-19 or prior coronaviruses for rare NMDs. Infection is a common trigger of exacerbation or disease progression in many NMDs, both inherited and immune-mediated. For example, infection has been the leading cause of exacerbation of myasthenia gravis (MG) in a retrospective study. ${ }^{15}$ As such, we expect that we will observe both increased rates of disease worsening and an increased incidence of new presentations during the COVID-19 pandemic.

Considerations for exacerbation in acquired and inherited disorders are primarily related to degree of baseline cardiac and respiratory dysfunction, bulbar weakness, underlying pathophysiology of disease, and related comorbid conditions. An updated review of consideration by disease has been compiled. ${ }^{16}$ Patients with motor neuron disease (e.g., amyotrophic lateral sclerosis [ALS], spinal muscular atrophy) and hereditary neuropathies with ventilatory muscle involvement may be particularly susceptible to infection. Those with metabolic myopathies (e.g., lipid storage diseases and mitochondrial disorders) are at increased risk of rhabdomyolysis with fever, infection, or fasting (attributable to loss of appetite). In addition, patients with various muscular dystrophies, including myotonic dystrophy, and metabolic diseases (e.g., Pompe disease) who have ventilatory muscle weakness or cardiomyopathy are likely at increased risk for severe COVID-19. Patients who develop COVID-19 may not return to their prior baseline. 


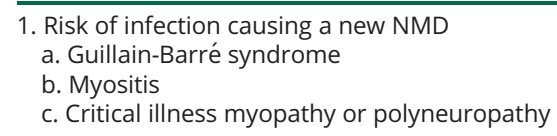

2. Risk of infection exacerbating known or unmasking previously unrecognized NMD

a. Autoimmune disorders such as CIDP, MADSAM, MMN, MG, LEMS, myositis

b. Degenerative disorders such as ALS, SMA, hereditary neuropathies, muscular dystrophies, congenital myopathies, mitochondrial myopathies, metabolic myopathies, and others

3. Risks of immunosuppressant/immunomodulating therapies in patients with autoimmune NMD

a. Increased risk of COVID-19 infection and more severe disease

b. Increased risks and severity of other infections in patients with COVID-19 in the setting of NMD treated with certain immunotherapies

c. Immunotherapies might make vaccines less effective

4. Risks of treatments for COVID-19

a. Hydroxychloroquine and chloroquine can cause a toxic neuropathy and myopathy

b. Antiviral treatments: lopinavir/ritonavir, remdesivir, others

5. Risks of vaccinations

a. Possible inflammatory neuropathy (e.g., Guillain-Barré syndrome, plexitis, mononeuritis)

Abbreviations: ALS = amyotrophic lateral sclerosis; CIDP = chronic inflammatory demyelinating polyneuropathy; LEMS = Lambert-Eaton myasthenic syndrome; MADSAM = multifocal acquired demyelinating sensory and motor neuropathy; $\mathrm{MG}$ = myasthenia gravis; $\mathrm{MMN}=$ multifocal motor neuropathy; $\mathrm{NMD}=$ neuromuscular disorder; SMA = spinal muscular atrophy.

\section{Risks of immunosuppressant and immunomodulating therapies in patients with autoimmune NMDs}

Patients with NMDs who use immunosuppressive therapies (ISTs) are likely at increased risk of contracting COVID-19 or having a more severe course of the virus. This risk is variable even among patients on ISTs and with the same disease (table 3). Published experience from Wuhan, China, to date has not examined neuromuscular comorbidities or patients on ISTs. ${ }^{5,6}$ In looking to similar immunocompromised populations where there has been work published, recent data suggest a trend toward increased incidence rate of COVID-19 and increased rate of severe disease in patients with cancer and cancer survivors in China. ${ }^{17}$ As a result, the authors made recommendations for this population that may be applicable to immunocompromised patients with NMD at highest risk: (1) intentional postponing of adjuvant chemotherapy or elective surgery for stable cancer in endemic areas, (2) stronger personal protection provisions for patients with cancer or cancer survivors, and (3) consideration of more intensive surveillance or treatment when patients with cancer are infected with SARS coronavirus 2 (SARS-CoV-2), especially in older patients or those with other comorbidities. ${ }^{17}$

In terms of managing ISTs, consensus statements are emerging to guide patients and clinicians until we have data published on outcomes. ${ }^{18}$ Most outpatients without infection should continue to take their medications, with instructions to call their neurologist and temporarily hold the medication if they develop symptoms of infection. In some cases, after discussion of risk and benefit between the patient and provider, some patients may be able to continue ISTs or be treated with a different, less immunosuppressive option. This involves a discussion of potential risks and benefits related to COVID-19 and underlying neuromuscular disease when adjusting doses or stopping immunosuppressant or immunomodulatory therapies. Examples of risk include age, comorbid medical problems, geographic location, household or occupational risk factors, and underlying neuromuscular disease severity. Avoiding abrupt cessation of a medication that may precipitate a flare of the underlying condition, which could in turn necessitate higher doses of prednisone, IST, or hospital admission, is the goal. Holding or suspending prednisone is not recommended.

Some therapies are not expected to increase the risk of COVID-19 or severe disease, including immunoglobulin therapy (intravenous or subcutaneous), complement inhibitor therapy (e.g., eculizumab), therapeutic plasma exchange, or neonatal $F c$ receptor $(\mathrm{FcRn})$ antagonists (various forms are now being assessed in clinical research trials). Reliance on infusion centers may increase the overall risks for patients, so switching to home visits with or without visiting nurses for these therapies (visiting nurses are not necessary after training for subcutaneous infusions) may mitigate but not eliminate the risks. Therefore, requirement for IV administration needs to be taken into risk/benefit discussions. Importantly, guidance statements are changing and risks and benefits of IST may change over time. Check-ins from high-risk patients with changes in circumstances are appropriate. At this time, for most patients, we are working primarily on education regarding risk reduction. Infrequently, we make preemptive COVID-19related medication adjustments in dosing or drug. In the future, vaccination or knowledge that a patient has developed immunity to COVID-19 could be incorporated into risk stratification and treatment decisions regarding further IST. ${ }^{19}$

Additional specific guidance for patients with NMDs based on drug regimen is outlined in table 4. For all patients, steps towards efficient prescribing to promote social distancing by 
Table 2 Coronavirus 2019 (COVID-19) risk by neuromuscular disease

\begin{tabular}{|c|c|c|}
\hline Disorder & $\begin{array}{l}\text { Level of risk for COVID-19 or having severe } \\
\text { COVID-19 disease course }\end{array}$ & Comments \\
\hline Motor neuron disease & Moderate/high & $\begin{array}{l}\text { Higher risk related to more advanced disease, use of ventilator or noninvasive } \\
\text { ventilation, dysphagia, comorbid diseases }\end{array}$ \\
\hline \multicolumn{3}{|l|}{ Neuropathies } \\
\hline Inherited & All levels & $\begin{array}{l}\text { Low with uncomplicated neuropathy } \\
\text { High with autonomic involvement or cardiac involvement (e.g., amyloidosis), } \\
\text { scoliosis with respiratory involvement }\end{array}$ \\
\hline Immune-mediated & All levels & $\begin{array}{l}\text { Related to degree of immunosuppressive therapy and respiratory/bulbar } \\
\text { weakness }\end{array}$ \\
\hline $\begin{array}{l}\text { Idiopathic, } \\
\text { nutritional, toxic }\end{array}$ & Low & No appreciable increased risks \\
\hline \multicolumn{3}{|l|}{ NMJ } \\
\hline LEMS & All levels & Consider underlying malignancy/chemotherapy \\
\hline gMG & All levels & Risk related to bulbar and respiratory weakness, immunosuppressive therapy \\
\hline CMS & All levels & $\begin{array}{l}\text { Adult-onset, stable for }>10 \text { years without bulbar or respiratory weakness likely } \\
\text { low risk } \\
\text { Actual or possible (based on mutation) bulbar or respiratory muscle weakness } \\
\text { higher risk }\end{array}$ \\
\hline \multicolumn{3}{|l|}{ Muscle } \\
\hline Inherited & All levels & $\begin{array}{l}\text { Risk related to bulbar and respiratory weakness } \\
\text { Related disease-specific comorbidities (i.e., diabetes, cardiac disease) } \\
\text { influences risk }\end{array}$ \\
\hline $\begin{array}{l}\text { Inflammatory/ } \\
\text { immune- } \\
\text { mediated }\end{array}$ & All levels & IST determines risk \\
\hline
\end{tabular}

Abbreviations: CMS = congenital myasthenic syndromes; gMG = generalized myasthenia gravis; IST = immunosuppressive therapy; LEMS = Lambert-Eaton myasthenic syndrome; NMJ = neuromuscular junction.

minimizing trips to pharmacies is appropriate. This may include refilling prescriptions for 90 days and encouraging delivery through mail order pharmacies. Weighing benefits of transitioning from infusion centers to home infusions will depend on patients' overall COVID-19 risk, transportation needs, geography/local resources, and insurance coverage. The relative risk of COVID-19 at hospital-based centers compared to home infusion is unknown.

\section{COVID-19 vaccine efficacy and access in NMDs}

Robust COVID-19 vaccine development programs with multiple candidates have launched. ${ }^{19-21}$ Typically a yearslong process, the timeline has been accelerated. Multiple types of vaccine candidates are in preclinical development. Two that are currently in phase I clinical trials are RNA and nonreplicating vector vaccines. ${ }^{21}$ To our knowledge, there are no live virus vaccines under consideration. This is important for immunosuppressed patients as live vaccines must be avoided. Whether immunosuppressive or immunomodulatory therapy will make the COVID-19 vaccines less effective is highly relevant for patients with NMDs and will need study. Recommendations for timing of vaccine administration with relation to dosing schedule of immunosuppressive or immunomodulatory therapies, including IV immunoglobulin, therapeutic plasma exchange, FcRn antagonists, and B-cell-depleting therapies, will be needed to maximize protective benefits. In addition, challenges of adequate vaccine supply during a pandemic and fair allocation based on risk are being addressed. ${ }^{21,22} \mathrm{We}$ anticipate that data provided by disease-specific neuromuscular groups during this time on risk for and outcomes of COVID-19 in these groups will greatly inform risk stratifications in the future. Pragmatically, we will also need to consider how patients with NMD receiving telemedicine or who are self-isolating will receive vaccination, when available.

\section{Management of patients with NMD who develop COVID-19}

At this time, there are no neuromuscular-specific recommendations for patients who contract COVID-19 and additional outcome data are needed. Monitoring moderate to high risk patients with NMDs closely for the possibility of more 
Table 3 Factors increasing risk of contracting coronavirus 2019 (COVID-19) or having more severe disease

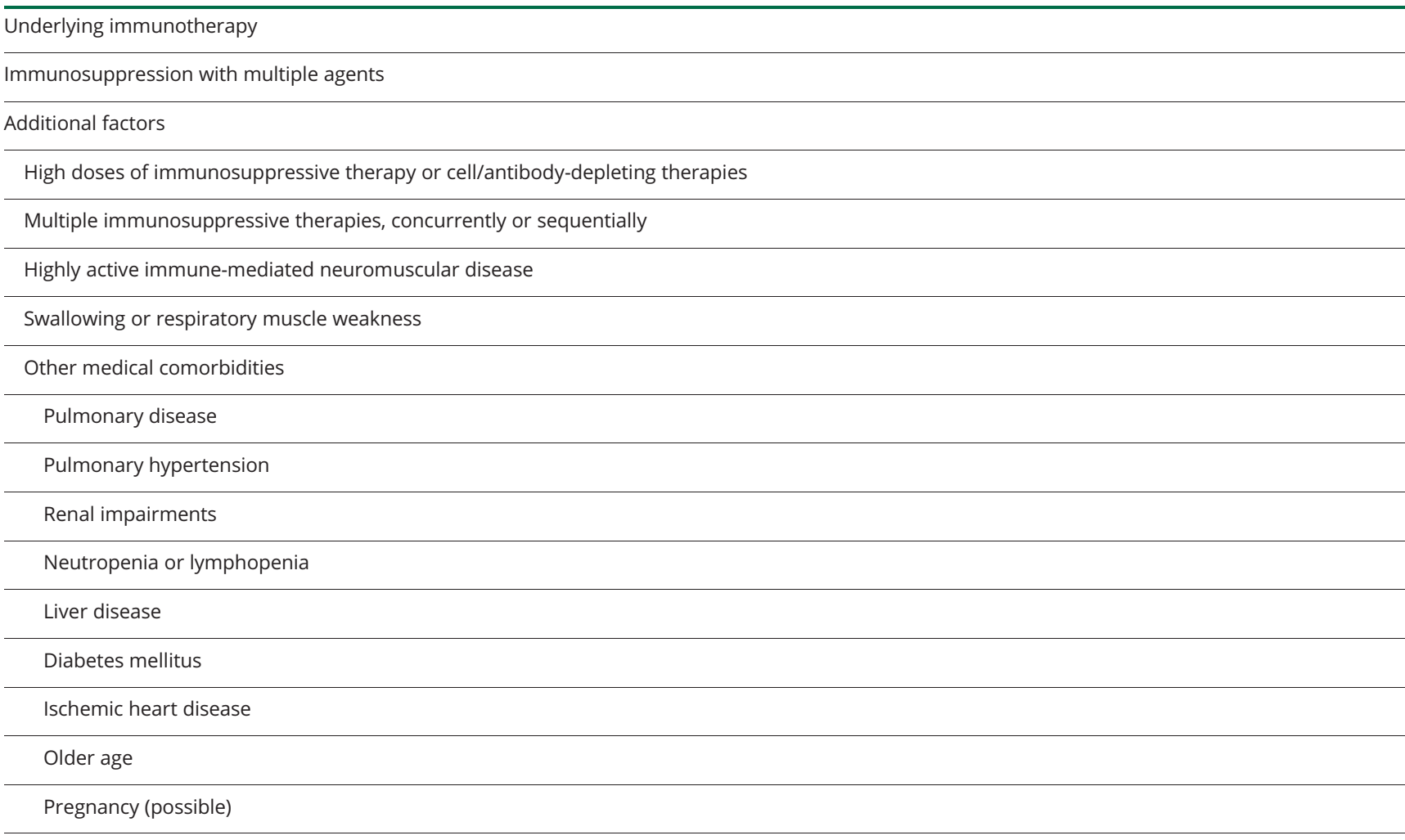

rapid decline in respiratory function or for worsening of their underlying neuromuscular disease is recommended. Telehealth applications could be considered in the future for this remote monitoring. Corticosteroids are not routinely given for treatment of COVID-19 but are sometimes used in sepsis. A discussion of the potential pros and cons of additional corticosteroids is available. ${ }^{23}$ Patients with NMD already on corticosteroids may require stress doses. Typically, other immunosuppression is held or continued based on the patient's clinical status from COVID-19 and the severity of their underlying NMD. Discussion with the patient's primary neurologist and inpatient consult team if unavailable is recommended.

\section{Risks of treatments for COVID-19}

Several antiviral drugs are in clinical trial for treatment of COVID-19, including lopinavir/ritonavir, used for HIV infection, and remdesivir, which inhibits viral RNA polymerases and appears to show potent activity in vitro against members of the filoviruses (e.g., Ebola virus) and coronaviruses (e.g., SARS$\mathrm{CoV}, \mathrm{MERS}-\mathrm{CoV}){ }^{24}$ A recently published trial from China found no efficacy of lopinavir/ritonavir in COVID-19, ${ }^{25}$ but other trials are ongoing and in preparation. With this in mind, certain protease inhibitors may increase the risk of peripheral neuropathy in patients with $\mathrm{HIV},{ }^{26}$ but other studies have found lopinavir/ritonavir does not increase the risk and may actually reduce the risk of distal sensory polyneuropathy in HIV-infected individuals. ${ }^{27,28}$ Given the duration of treatment in patients with COVID-19 infection, we would suspect the likelihood of inducing or worsening a preexisting polyneuropathy with lopinavir/ritonavir is likely to be low. However, a toxic myopathy with rhabdomyolysis has been reported in several cases of lopinavir/ritonavir treatment in combination with a statin. ${ }^{29-32}$ This is particularly important given early use of empiric highdose statins for COVID-19 and the independent association of statins with rhabdomyolysis. ${ }^{43}$ A small study suggested that remdesivir and chloroquine may be effective in reducing 2019$\mathrm{nCoV}$ infection in vitro ${ }^{33}$ and clinical trials of these agents are underway. Of note, no definite NMDs were associated with remdesivir in a trial for Ebola, though pain in the arms and legs was noted as a common complaint in healthy controls. ${ }^{34}$

Chloroquine and hydroxychloroquine have also been mentioned as possible treatment for COVD-19. They are being used in patients with infection and without proven benefit as prophylaxis. Both drugs are associated with potential neuromuscular side effects. ${ }^{35,36}$ In vitro studies have demonstrated that chloroquine blocked COVID-19 infection, as mentioned above. ${ }^{36} \mathrm{~A}$ short report of 100 patients in China noted that chloroquine seemed to be beneficial, but without supportive data. ${ }^{37}$

Rarely, patients taking chloroquine or hydroxychloroquine develop slowly progressive, painless, proximal weakness and atrophy in the legs more than the arms. ${ }^{38-43}$ In addition, lengthdependent sensory loss and reduced muscle stretch reflexes, particularly at the ankle, may be related to a concomitant neuropathy. Cardiac muscle can also be affected, leading to a cardiomyopathy. Serum CK levels are usually slightly elevated. Motor and sensory nerve conductions may show reduced 
Table 4 Patients with neuromuscular disease without coronavirus 2019 (COVID-19): treatment-specific guidance

\begin{tabular}{|c|c|c|c|}
\hline $\begin{array}{l}\text { Treatment type/medication } \\
\text { class }\end{array}$ & Examples & $\begin{array}{l}\text { Disorders } \\
\text { included }\end{array}$ & Guidance \\
\hline $\begin{array}{l}\text { Symptomatic and other } \\
\text { therapies }\end{array}$ & $\begin{array}{l}\text { Riluzole, botulinum toxins, antiepileptics, } \\
\text { benzodiazepines, pyridostigmine, diaminopyridine, } \\
\text { SSRIs, SNRIs, oral albuterol, mexiletine }\end{array}$ & $\begin{array}{l}\text { ALS } \\
\text { ALS-related } \\
\text { sialorrhea } \\
\text { Neuropathic } \\
\text { pain } \\
\text { Muscle cramps } \\
\text { MG/LEMS } \\
\text { CMS } \\
\text { Myotonic } \\
\text { disorders }\end{array}$ & $\begin{array}{l}\text { No specific dose change } \\
\text { Consider risk/benefit of routine monitoring } \\
\text { laboratory studies } \\
\text { Postpone nonurgent botulinum toxin } \\
\text { injections } \\
\text { Rx of controlled substances now typically } \\
\text { approved via virtual care with standard } \\
\text { safeguards }\end{array}$ \\
\hline $\begin{array}{l}\text { Nonimmunomodulatory } \\
\text { infusion and intrathecal } \\
\text { therapies, gene therapies }\end{array}$ & $\begin{array}{l}\text { Edaravone, nusinersen/zolgensma, patisiran/ } \\
\text { inotersen, lumizyme/myozyme }\end{array}$ & $\begin{array}{l}\text { ALS } \\
\text { SMA } \\
\text { Hereditary } \\
\text { aTTR } \\
\text { amyloidosis } \\
\text { Pompe }\end{array}$ & $\begin{array}{l}\text { Consider home infusions } \\
\text { Consider risk of exposures with infusions vs } \\
\text { risk of treatment interruption }\end{array}$ \\
\hline $\begin{array}{l}\text { Immunomodulatory } \\
\text { therapies }\end{array}$ & $\begin{array}{l}\text { IVIg } \\
\text { SClg } \\
\text { Plasma exchange } \\
\text { FCRn antagonists }\end{array}$ & $\begin{array}{l}\text { GBS } \\
\text { CIDP/MADSAM } \\
\text { MMN } \\
\text { MG } \\
\text { LEMS } \\
\text { Myositis }\end{array}$ & $\begin{array}{l}\text { Consider home infusions } \\
\text { Consider reducing frequency in stable } \\
\text { patients } \\
\text { Likely do not increase risk of virus }\end{array}$ \\
\hline
\end{tabular}

\begin{tabular}{|c|c|c|c|}
\hline Complement inhibitors & Eculizumab, clinical trials (zilucoplan, ravulizumab) & $\begin{array}{l}\text { MG } \\
\text { Immune- } \\
\text { mediated } \\
\text { necrotizing } \\
\text { myopathy }\end{array}$ & $\begin{array}{l}\text { Consider home infusions } \\
\text { May encounter logistical challenges for } \\
\text { meningococcal immunizations: limited } \\
\text { availability of walk-in facilities, etc. } \\
\text { Likely does not increase COVID-19 risk }\end{array}$ \\
\hline Corticosteroids & Prednisone, methylprednisolone, deflazacort & $\begin{array}{l}\text { CIDP/MADSAM } \\
\text { MG } \\
\text { LEMS } \\
\text { Myositis } \\
\text { DMD }\end{array}$ & $\begin{array}{l}\text { Consider lowest possible effective dose that } \\
\text { will prevent disease flare } \\
\text { Continue steroids unchanged in DMD } \\
\text { Consider stress dose as usual for illness } \\
\text { Avoid abrupt cessation for patients on } \\
\text { chronic steroids }\end{array}$ \\
\hline $\begin{array}{l}\text { Immunosuppressive } \\
\text { therapies }\end{array}$ & $\begin{array}{l}\text { Azathioprine, mycophenolate mofetil, } \\
\text { methotrexate, tacrolimus, cyclosporine }\end{array}$ & $\begin{array}{l}\text { CIDP/MADSAM } \\
\text { MG } \\
\text { LEMS } \\
\text { Myositis }\end{array}$ & $\begin{array}{l}\text { Consider risk/benefit of routine monitoring } \\
\text { laboratories, consider spacing } \\
\text { Continuation of therapy typically } \\
\text { recommended, consider dose reduction if } \\
\text { otherwise medically indicated } \\
\text { Consider delaying initiation in stable patient } \\
\text { with mild disease until height of pandemic } \\
\text { has passed }\end{array}$ \\
\hline $\begin{array}{l}\text { Immunosuppressive/cell } \\
\text { depleting therapies }\end{array}$ & $\begin{array}{l}\text { Rituximab, ocrelizumab, cyclophosphamide, clinical } \\
\text { trial drugs }\end{array}$ & $\begin{array}{l}\text { CIDP/MADSAM } \\
\text { MMN } \\
\text { MG } \\
\text { LEMS } \\
\text { Myositis }\end{array}$ & $\begin{array}{l}\text { Consider postponing infusions, spacing } \\
\text { dosing interval, or switching to a different } \\
\text { therapy } \\
\text { Avoid new starts unless no other good } \\
\text { alternative }\end{array}$ \\
\hline $\begin{array}{l}\text { Ancillary services/ } \\
\text { evaluations }\end{array}$ & $\begin{array}{l}\text { Physical therapy, occupational therapy, speech } \\
\text { therapy, clinical swallow evaluation, DME }\end{array}$ & All & $\begin{array}{l}\text { Indication is primarily urgent appointments } \\
\text { when ADL are limited and safety a concern } \\
\text { Consider telemedicine possibilities }\end{array}$ \\
\hline
\end{tabular}

Abbreviations: $\mathrm{ADL}=$ activities of daily living; $\mathrm{ALS}=$ amyotrophic lateral sclerosis; $\mathrm{CIDP}=$ chronic inflammatory demyelinating polyneuropathy; $\mathrm{CMS}=$ congenital myasthenic syndromes; DMD = Duchenne muscular dystrophy; DME = durable medical equipment; FcRn = neonatal Fc receptor; GBS = GuillainBarré syndrome; IVIg = IV immunoglobulin; LEMS = Lambert-Eaton myasthenic syndrome; MADSAM = multifocal acquired demyelinating sensory and motor neuropathy; MG = myasthenia gravis; MMN = multifocal motor neuropathy; SCIg = subcutaneous immunoglobulin; SMA = spinal muscular atrophy; SNRI = serotonin and norepinephrine reuptake inhibitor; SSRI = selective serotonin reuptake inhibitor.

amplitudes with slightly slow conduction velocities. Needle EMG can demonstrate positive sharp waves, fibrillation potentials, and myotonic discharges, particularly in proximal muscles. Autophagic vacuoles are often evident in skeletal and cardiac muscle fibers on biopsy. Usually, but not invariably, this toxic neuromyopathy does not develop unless patients are on high dosages for a year or more. Given that patients would receive a much shorter course of chloroquine and hydroxychloroquine, this toxic neuromyopathy is unlikely to occur. Chloroquine and hydroxychloroquine have also been associated with new-onset or worsening MG and are typically used with caution in this patient group. 44,45

Azithromycin, a macrolide antibiotic, is also being used with chloroquine or hydroxychloroquine for COVID-19. Macrolide therapy, however, the most common being azithromycin, was not associated with reduced 90-day mortality or 
Table 5 Educational resources for patients

1. Centers for Disease Control and Prevention (cdc.gov/coronavirus/2019-nCoV/index.html)

2. General resources compiled by the Muscular Dystrophy Association (mda.org/covid19)

3. Guidance for the management of myasthenia gravis and Lambert-Eaton myasthenic syndrome during COVID-19 by the International MG/COVID Working Group and a Webinar on myasthenia gravis and COVID by MGNET available on YouTube (myasthenia.org)

4. Recommendations for amyotrophic lateral sclerosis and specifically helpful suggestions for managing interactions with home health aides during COVID19 (als.ca/wp-content/uploads/2020/03/COVID-19-ALS-Clinician-Guidance-Document-2020-03-17-FINAL-EN.pdf)

improvement in MERS-CoV RNA clearance in a study of patients with MERS. ${ }^{46}$ Importantly, macrolides also may cause worsening of $\mathrm{MG}^{15}$

\section{Risk of incident NMD with COVID- 19 vaccine}

Another potential risk of vaccines is GBS and other acute inflammatory neuropathies (e.g., plexitis). This association is strongest for swine flu. A slight increased risk of GBS has been found in some studies of seasonal flu (influenza) vaccination ${ }^{47-49}$ but not all ${ }^{50}$ and regardless, the risk of influenza in most individuals outweighs the rare risk, if any, of GBS. Likewise, a small risk of GBS was reported in some ${ }^{51-55}$ but not all series $^{56,57}$ following H1N1 vaccination. These inflammatory neuropathies are thought to arise due to molecular mimicry as discussed previously between proteins on the virus and those on peripheral nerves. Certainly, this will be important to measure in future epidemiologic studies. There is no indication that a history of GBS or other immune-mediated neuromuscular disease would preclude vaccination against COVID-19 at this time.

\section{Changes in neuromuscular systems of care}

The COVID-19 pandemic has forced a rapid and unprecedented reorganization of clinical care delivery worldwide. In the United States, we are in the early stages of these modifications. Approach has been tailored by geographic location, local COVID-19 prevalence, patient population, and practice or institutional structures. Currently, the volume of elective or nonurgent outpatient care has been significantly reduced. The goal is to limit exposure to patients, communities, and medical staff. No data regarding the scope of this effect have been generated. The American Academy of Neuromuscular and Electrodiagnostic Medicine (AANEM) published guidance regarding clinical visits, electrodiagnostic testing, and telemedicine during COVID-19. ${ }^{57}$ Currently, the AANEM encourages physicians to "discuss issues related to patient care with their hospitals and provide their recommendations regarding which patients need to be seen vs those that can be delayed without impact on patient care or outcomes" and "carefully consider when to cancel nonurgent procedures or prioritize their more urgent patients in order to reduce potential exposure and to ensure judicious use of potentially limited supplies of personal protective equipment." Like many other institutions, we have adapted a triage system to allocate scheduled outpatients to in-person encounters, telemedicine encounters, or to delay the visit or procedure if medically appropriate. Most outpatient electrodiagnostic studies and muscle and nerve biopsies may be postponed unless in case of urgent need and the results would change management (e.g., new ALS, MG, immune-mediated neuropathy or myopathy). Relevant patient-related and disease-specific outcomes and systems-based measurements of care metrics should be evaluated to assess the effect of these modifications.

Access to ancillary services and evaluation has been affected by COVID-19. Outpatient pulmonary function tests may not be performed due to increased risks. On a local level, our speech therapy department had become credentialed to perform remote video swallow assessment prior to COVID-19 and therefore is able to continue this program. Fluoroscopic swallowing studies are currently performed only for patients whose dysphagia is unmanaged and may result in an unplanned hospitalization. Overall, however, dysphagia is being evaluated and treated as much as possible with video sessions. Outpatient physical therapists and occupational therapists have mainly been communicating with patients by phone and patient portal sessions, often sending photographs and videos of exercises or equipment. Most outpatient and home therapists are seeing only essential postoperative patients in our region. The American Physical Therapy Association and state-based physical therapy organizations are organizing regarding telemedicine. Some of our local occupational therapists can provide virtual visits for follow-up for established patients. Medical equipment (e.g., wheelchairs, Hoyer lifts) deliveries and custom bracing have been significantly delayed in some regions. Virtual ancillary services have been discussed in previous publications. ${ }^{58,59}$

We have compiled a list of common resources for patients who have general inquiries about COVID-19 (table 5). Directing patients to websites and other resources that are updated regularly is paramount, so that they have up-to-date information when they choose to access the information. Disease-specific links relating to ALS, MG, and recommendations for patients who require home health aides are included. Family and caregivers should be aware of their own ability to spread COVID-19. In addition, high-flow noninvasive ventilation 
Table 6 Telemedicine: Proposed utility/appropriateness by neuromuscular outpatient visit type during coronavirus 2019 (COVID-19)

\begin{tabular}{|c|c|c|}
\hline $\begin{array}{l}\text { High utility/ } \\
\text { appropriateness }\end{array}$ & Moderate utility/appropriateness & Low utility/appropriateness \\
\hline $\begin{array}{l}\text { NMD follow-up } \\
\text { PN follow-up: stable or } \\
\text { management of } \\
\text { neuropathic pain } \\
\text { MG follow-up: stable } \\
\text { Myositis follow-up: stable } \\
\text { Inherited neuropathy or } \\
\text { myopathy follow-up: stable }\end{array}$ & $\begin{array}{l}\text { New or unstable NMD } \\
\text { New or unstable PN } \\
\text { New MG: well-established diagnosis or unstable } \\
\text { new/follow-up } \\
\text { All patients with worsening symptoms to triage } \\
\text { need and timeframe for further or more urgent } \\
\text { care }\end{array}$ & $\begin{array}{l}\text { All patients with discrepancy between reported symptoms and abnormal } \\
\text { examination findings } \\
\text { All disorders: second opinions for patients where nuances of physical } \\
\text { examination will highly influence medical decision-making and diagnostic } \\
\text { evaluation } \\
\text { Primary management of unstable patients }\end{array}$ \\
\hline
\end{tabular}

Abbreviations: MG = myasthenia gravis; NMD = neuromuscular disorder; $\mathrm{PN}$ = peripheral neuropathy.

aerosolizes infectious particles to the local environment and requires appropriate measures to prevent spread.

\section{Rapid integration of telemedicine}

Before COVID-19, the rollout of telehealth in neurology and particularly in neuromuscular medicine had been slow. ${ }^{60}$ Now, within a 2-week time period, many institutions in the United States have transitioned heavily to telemedicine due to necessity and relaxation of prior regulatory limitations. ${ }^{61}$ Contributing factors to slow adaptation before COVID-19 were reliance on a nuanced strength, sensation, and reflex examination in neuromuscular encounters. ALS clinics were early adapters prior to COVID-19. ${ }^{62}$ Neuromuscular clinics and information about incorporation of trainees are underrepresented in the limited data about outpatient telemedicine in neurology. ${ }^{63,64}$ Resources and telemedicine references have been created by numerous professional societies including the American Academy of Neurology and the American Association for Neuromuscular and Electrodiagnostic Medicine.

With necessity to switch to telemedicine for most outpatient encounters, neurologists are quickly discovering the strengths and limitations of telemedicine, and new tools and skills required. It is important to keep in mind that these strengths and limitations are not likely fully reflective of care in absence of the pandemic. ${ }^{65}$ For example, coordinating local laboratory or imaging evaluation and pulmonary function testing, which is typically straightforward, is now layered with additional challenge and discussion of potential added COVID-19 exposure. We have transformed most attending only and resident/fellows clinics into telemedicine clinics to continue to provide both patient care and clinical training. Limitations in the physical examination preclude billing based on current complexity requirements in most circumstances. Currently, for virtual/phone visits that replace outpatient visits, billing is based primarily on the attending's synchronous video face-to-face time or time-based synchronous phone interaction time with the patient. This billing structure has been reviewed in detail elsewhere and will likely need modification if ongoing incorporation of residents and fellows in outpatient neuromuscular telemedicine will continue. ${ }^{66}$ In addition, best practices for performance of and billing for virtual disease-specific neuromuscular examinations and scales as well as incorporation of trainees into outpatient telemedicine settings is needed. To date, the visits that we perceive have the highest and lowest benefit for telemedicine during the COVID-19 pandemic are outlined in table 6. Further studies on outcomes and resource utilization as well as patient and provider satisfaction with virtual visits will further inform what portions of this emergency telemedicine will endure beyond COVID.

\section{COVID-19's effect on neuromuscular training}

In addition to professional and personal challenges for trainees and teaching faculty and clinical reassignments, the COVID-19 pandemic has posed limitations on formal neuromuscular training in residencies and fellowships. We see the immediate effect for this year's cohort, but anticipate that next year will also be affected, either by ongoing reallocated clinical volume or the need to catch up on differed routine outpatient care. To adapt to these changes in real time and plan for the months ahead, we have added new or modified fellowship activities, and involved fellows in creating and testing these new structures (table 7). We have found that new communication platforms (e.g., Microsoft Teams or other) have been essential for ongoing formal and informal communications and to facilitate synchronous supervision of fellows remotely in clinic. Readers of Neurology ${ }^{\circledR}$ will have developed additional novel educational strategies. We anticipate that there will be future collaboration around these innovations to build and, after COVID-19, continuing those that have positively affected training.

\section{COVID-19's effect on neuromuscular research}

The effect of COVID-19 is of course not limited to neuromuscular research but will affect all medical specialties and neurology subspecialties. We will focus on the effect in clinical research, but certainly basic science and translation research will be affected. For example, basic/translational researchers, 
Table 7 Early effect of coronavirus 2019 (COVID-19) on neuromuscular training activities

\begin{tabular}{|c|c|c|}
\hline Increased & Decreased & Skill development \\
\hline $\begin{array}{l}\text { Virtual education (lecture series, waveform conference, } \\
\text { pathology conference, grand rounds) } \\
\text { Electrodiagnostic testing, neuromuscular medicine, } \\
\text { muscle and nerve histopathology self-study } \\
\text { Neuromuscular ultrasound self-study } \\
\text { Communication with patients by phone and patient portal }\end{array}$ & $\begin{array}{l}\text { Bedside teaching } \\
\text { In-person and multidisciplinary clinics } \\
\text { Electrodiagnostic testing study volume, } \\
\text { inpatient and outpatient } \\
\text { Biopsy performance } \\
\text { Neuromuscular ultrasound } \\
\text { performance } \\
\text { Time spent on clinical notes } \\
\text { Work exclusively within the } \\
\text { neuromuscular division } \\
\text { Work in established systems of care }\end{array}$ & $\begin{array}{l}\text { Telemedicine } \\
\text { Increased participation in hospital organization as } \\
\text { a whole } \\
\text { Developing new systems of care as a team, quality } \\
\text { improvement processes } \\
\text { New opportunities for formal teaching of medical } \\
\text { students and residents } \\
\text { Increased academic work, particularly that } \\
\text { immediately relevant to COVID-19 } \\
\text { Training in formal and informal remote working } \\
\text { skills, individual and team-based }\end{array}$ \\
\hline
\end{tabular}

including graduate students and laboratory technicians, may not be considered essential employees and will need to work from home. Experimental studies on animals are being disrupted. From our perspective of clinical researchers, there are many challenges and we have selected some practical issues to highlight.

1. There are challenges to new study start-up and close out of recently completed trials. Site initiation visits and routine monitoring by the sponsor of studies is being prohibited in many academic hospitals. Those recently completed studies may not be able to analyze data until the monitor verifies source documents and what has been entered into study databases. These difficulties may be mitigated by allowing virtual study visits and monitoring.

2. Food and Drug Administration (FDA) guidance suggests limiting on-site study visits to only those with conditions in which available treatment options are limited and in which the research drug has potential for benefit. The clinical researcher weighs risks and benefits with each individual participant in each clinical trial.

3. Research sites need to have the appropriate staffing to maintain a clinical trial. Physician and nurse investigators may be deployed from research duties to help manage patients in the hospital. Likewise, research phlebotomists, pharmacists, and other research staff may be shifted to areas of the hospital where they may be more needed. Study coordinators may not be considered essential employees. Backups are needed for research personnel in case they get pulled away from research duties or become ill themselves.

4. It may be impossible for study participants to return to the site for their research appointments because their own illness puts them at increased risk in addition to what was mentioned above. We need to convert as many study visits as possible to virtual/phone visits, arrange for study laboratories to be done locally close to where a participant lives, and results to be sent back to the research site. We will need regulators (e.g., FDA, European Union) to understand that these laboratory studies that were supposed to be sent and analyzed by a previously approved central laboratory are going to be done locally in many cases. Research needs to figure out how to analyze the results coming from many laboratories.
Furthermore, we need to figure out how to handle laboratory results in which the investigator was to be blinded (e.g., such as CK levels in myositis trials). We may need to add blinded coordinators assigned to handle mail and faxes for these participants from their local laboratories to be placed in research binders. We also need to address how to handle missing data, particularly those involving primary outcome measures. Importantly, we have to arrange for study drugs to be shipped to participants and perform necessary oversight to ensure participants are taking the study drug (e.g., collecting and counting pills/syringes).

5. There is more administrative work for investigators and coordinators. The above changes to an approved protocol are considered protocol deviations (albeit minor given the situation), but require submissions to institutional review boards as well as approval of new amendments and informed consent forms.

6. Enrollment for clinical research is going to be slower and studies take longer to complete than anticipated. This is challenging to handle on a fixed budget on a grant.

Readers will think of more obstacles to research and how we might mitigate these and others. We will all need to learn from each other during these trying times.

\section{Discussion}

Data from the current COVID-19 pandemic regarding specific risks and outcomes for patients with neuromuscular disease are unknown. We will need new clinical structures including robust telemedicine platforms and procedures to care for our patients and to continue to educate trainees during this time. Expedited publication of updated evidence-based guidance will be informative. In the meantime, we can be vigilant in assessing patients with neuromuscular disease for potential neuromuscular complications of COVID-19 and work towards mitigation of COVID-19-related risk for patients with preexisting neuromuscular disease. Collaborative efforts among institutions will help generate the data needed to inform management of rare NMDs in the setting of COVID-19 and maintain clinical trials and research despite current challenges. 


\section{Acknowledgment}

The authors thank the Partners neuromuscular fellowship class of 2020 (Joome Suh, MD; Leeann Burton, MD; Michael Slama, MD, PhD; Sarah Madani, MD; Ariel Marks, MD; and Salman Bhai, MD) and Chris Doughty, MD, associate fellowship program director, for input on both telemedicine and neuromuscular training during COVID-19; Virginia Clarke, RN, and the MGH Medical Infusion Center staff for their work, dedication, and innovation; William S. David, MD, $\mathrm{PhD}$, for leadership; Amy Swartz, PT, Katherine Burke, PT, and Stacey Sullivan, speech therapist, for input regarding $\mathrm{PT} / \mathrm{OT}$ and speech therapy during COVID; The Autoimmune Neurology division at Massachusetts General Hospital and the International MG/COVID workgroup for collaborative approaches to shared new clinical challenges; research study coordinators Louis Beers and Marie Guthrie and research physical therapists Patricia Flynn, PT, and Emily Russo, PT, for assisting in the evaluation of research participants; and EMG/NCTs, including Peter McKeon, Catherine MacInnes, Rosemary Difrancisco, and Abdusamad Essa, and administrative assistants and practice managers, including Darlene Young and Tamika Scott, for triaging hundreds of patient phone calls, rescheduling neuromuscular clinics to virtual appointments, and moving EMG and biopsy appointments to later dates.

\section{Study funding}

No targeted funding reported.

\section{Disclosure}

A.C. Guidon has served as a consultant or on a medical advisory board for Alexion, Momenta, and Ra Pharma; has received royalties from Oakstone Publishing; and receives grant funding from the Myasthenia Gravis Foundation of America. A.A. Amato is Associate Editor for Neurology and received royalties from Oakstone Publishing, Neuromuscular Disorders, Harrison's Principles of Internal Medicine, and Up-to-Date, and has served as a consultant or on medical advisory board for Alexion and Argenx. Go to Neurology.org/N for full disclosures.

\section{Publication history}

Received by Neurology April 5, 2020. Accepted in final form April 9, 2020.

\section{Appendix Authors}

\begin{tabular}{|c|c|c|}
\hline Name & Location & Contribution \\
\hline $\begin{array}{l}\text { Amanda } \\
\text { C. } \\
\text { Guidon, } \\
\text { MD }\end{array}$ & $\begin{array}{l}\text { Division of Neuromuscular } \\
\text { Medicine, Department of } \\
\text { Neurology, Massachusetts } \\
\text { General Hospital, Harvard } \\
\text { Medical School, Boston }\end{array}$ & $\begin{array}{l}\text { Major role in departmental } \\
\text { actions contributing to } \\
\text { content, drafted and revised } \\
\text { the manuscript for } \\
\text { intellectual content }\end{array}$ \\
\hline $\begin{array}{l}\text { Anthony } \\
\text { A. } \\
\text { Amato, } \\
\text { MD }\end{array}$ & $\begin{array}{l}\text { Division of Neuromuscular } \\
\text { Medicine, Department of } \\
\text { Neurology, Brigham and } \\
\text { Woman's Hospital, Harvard } \\
\text { Medical School, Boston, MA }\end{array}$ & $\begin{array}{l}\text { Major role in departmental } \\
\text { actions contributing to } \\
\text { content, drafted and revised } \\
\text { the manuscript for } \\
\text { intellectual content }\end{array}$ \\
\hline
\end{tabular}

\section{References}

1. Zhao H, Shen D, Zhou H, Liu J, Chen S. Guillain-Barré syndrome associated with SARS-CoV-2 infection: causality or coincidence? Lancet Neurol Epub 2020 April 1.

2. Kim JE, Heo JH, Kim HO, et al. Neurological complications during treatment of Middle East respiratory syndrome. J Clin Neurol 2017;13:227-233.

3. Sharma K, Tengsupakul S, Sanchez O, Phaltas R, Maertens P. Guillain-Barré syndrome with unilateral peripheral facial and bulbar palsy in a child: a case report. SAGE Open Med Case Rep 2019;7:2050313X19838750

4. Turgay C, Emine T, Ozlem K, Muhammet SP, Haydar AT. A rare cause of acute flaccid paralysis: human coronaviruses. J Pediatr Neurosci 2015;10:280-281.

5. Huang C, Wang Y, Li X, et al. Clinical features of patients infected with 2019 novel coronavirus in Wuhan, China. Lancet 2020;395:497-506.

6. Wang D, Hu B, Hu C, et al. Clinical characteristics of 138 hospitalized patients with 2019 novel coronavirus-infected pneumonia in Wuhan, China. JAMA Epub 2020 Feb 7.

7. Wang JT, Sheng WH, Fang CT, et al. Clinical manifestations, laboratory findings, and treatment outcomes of SARS patients. Emerg Infect Dis 2004;10:818-824.

8. Fan CK, Yieh KM, Peng MY, Lin JC, Wang NC, Chang FY. Clinical and laboratory features in the early stage of severe acute respiratory syndrome. J Microbiol Immunol Infect 2006;39:45-53.

9. Chen LL, Hsu CW, Tian YC, Fang JT. Rhabdomyolysis associated with acute renal failure in patients with severe acute respiratory syndrome. Int J Clin Pract 2005;59: $1162-1166$

10. Tsai LK, Hsieh ST, Chao CC, et al. Neuromuscular disorders in severe acute respiratory syndrome. Arch Neurol 2004;61:1669-1673.

11. Leung TW, Wong KS, Hui AC, et al. Myopathic changes associated with severe acute respiratory syndrome: a postmortem case series. Arch Neurol 2005;62:1113-1117.

12. Arabi YM, Deeb AM, Al-Hameed F, et al; the Saudi Critical Care Trials group. Macrolides in critically ill patients with Middle East respiratory syndrome. Int J Infect Dis 2019;81:184-190.

13. Algahtani H, Subahi A, Shirah B. Neurological complications of Middle East re spiratory syndrome coronavirus: a report of two cases and review of the literature. Case Rep Neurol Med 2016;2016:3502683.

14. Torbic H, Duggal A. Neuromuscular blocking agents for acute respiratory distress syndrome. J Crit Care 2019;49:179-184.

15. Gummi RR, Kukulka NA, Deroche CB, Govindarajan R. Factors associated with acute exacerbations of myasthenia gravis. Muscle Nerve 2019;60:693-699.

16. Association of British Neurologists. Association of British Neurologists guidance on COVID-19 for people with neurological conditions, their doctors and carers. Published March 22, 2020. Available at: https://cdn.ymaws.com/www.theabn.org/ resource/collection/6750BAE6-4CBC-4DDB-A684-116E03BFE634/ABN_Neurology_ COVID-19 Guidance 22.3.20.pdf. Accessed on April 9, 2020

17. Liang W, Guan W, Chen R, et al. Cancer patients in SARS-CoV-2 infection: a nationwide analysis in China. Lancet Oncol 2020;21:335-337.

18. Jacob S, Muppidi S, Guidon A, et al. Guidance for the management of myasthenia gravis (MG) and Lambert-Eaton myasthenic syndrome (LEMS) during the COVID19 pandemic.J Neurol Sci 2020;412:116803.

19. Prompetchara E, Ketloy C, Palaga T. Immune responses in COVID-19 and potential vaccines: lessons learned from SARS and MERS epidemic. Asian Pac J Allergy Immunol 2020;38:1-9.

20. Fauci AS, Lane HC, Redfield RR. COVID-19: navigating the uncharted. N Engl J Med 2020;382:1268-1269.

21. Lurie N, Saville M, Hatchett R, et al. Developing COVID-19 vaccines at pandemic speed. N Engl J Med Epub 2020 Mar 30.

22. WHO Vaccine Blueprint [Internet]. 2020. Available at: https://www.who.int/blueprint/priority-diseases/key-action/novel-coronavirus-landscape-ncov.pdf. Accessed April 9, 2020.

23. World Health Organization. Clinical Management of Severe Acute Respiratory In fection (SARI) When COVID-19 Disease Is Suspected. Geneva: World Health Organization; 2020:1-21.

24. Martinez MA. Compounds with therapeutic potential against novel respiratory 2019 coronavirus. Antimicrob Agents Chemother Epub 2020 Mar 9.

25. Cao B, Wang Y, Wen D, et al. A trial of lopinavir-ritonavir in adults hospitalized with severe covid-19. N Engl J Med Epub 2020 Mar 18.

26. Ellis RJ, Marquie-Beck J, Delaney P, et al. Human immunodeficiency virus protease inhibitors and risk for peripheral neuropathy. Ann Neurol 2008;64:566-572.

27. Vermaak JR, Dave JA, Levitt N, Heckmann JM. Sensory neuropathy and metabolic risk factors in human immune deficiency virus infected South Africans receiving protease inhibitors. AIDS Res Ther 2015;12:30.

28. Arenas-Pinto A, Thompson J, Musoro G, et al; EARNEST Trial Team. Peripheral neuropathy in HIV patients in sub-Saharan Africa failing first-line therapy and the response to second-line ART in the EARNEST trial. J Neurovirol 2016;22:104-113.

29. Benveniste O, Longuet P, Duval X, Le Moing V, Leport C, Vildé JL. Two episodes of acute renal failure, rhabdomyolysis, and severe hepatitis in an AIDS patient successively treated with ritonavir and indinavir. Clin Infect Dis 1999;28:1180-1181.

30. Cheng $\mathrm{CH}$, Miller $\mathrm{C}$, Lowe $\mathrm{C}$, Pearson VE. Rhabdomyolysis due to probable interaction between simvastatin and ritonavir. Am J Health Syst Pharm 2002;59: 728-730.

31. Mah Ming JB, Gill MJ. Drug-induced rhabdomyolysis after concomitant use of clarithromycin, atorvastatin, and lopinavir/ritonavir in a patient with HIV. AIDS Patient Care STDs 2003;17:207-210.

32. de Kanter CT, Keuter M, van der Lee MJ, Koopmans PP, Burger DM. Rhabdomyolysis in an HIV-infected patient with impaired renal function concomitantly treated with rosuvastatin and lopinavir/ritonavir. Antivir Ther 2011;16:435-437. 
33. Wang M, Cao R, Zhang L, et al. Remdesivir and chloroquine effectively inhibit the recently emerged novel coronavirus (2019-nCoV) in vitro. Cell Res 2020;30: 269-271.

34. Mulangu S, Dodd LE, Davey RT Jr, et al. A randomized, controlled trial of Ebola virus disease therapeutics. N Engl J Med 2019;381:2293-2303.

35. Cortegiani A, Ingoglia G, Ippolito M, Giarratano A, Einav S. A systematic review on the efficacy and safety of chloroquine for the treatment of COVID-19. J Crit Care 2020;9441:30390-30397.

36. Guastalegname M, Vallone A. Could chloroquine/hydroxychloroquine be harmful in coronavirus disease 2019 (COVID-19) treatment? Clin Infect Dis Epub 2020 Mar 24. Letter.

37. Gao J, Tian Z, Yang X. Breakthrough: chloroquine phosphate has shown apparent efficacy in treatment of COVID-19 associated pneumonia in clinical studies. Biosci Trends 2020;14:72-73.

38. Eadie MJ, Ferrier TM. Chloroquine myopathy. J Neurol Neurosurg Psychiatry 1966; 29:331-337.

39. Joyce E, Fabre A, Mahon N. Hydroxychloroquine cardiotoxicity presenting as a rapidly evolving biventricular cardiomyopathy: key diagnostic features and literature review. Eur Heart J Acute Cardiovasc Care 2013;1:77-83.

40. Mastaglia FL, Papadimitriou JM, Dawkins RL, et al. Vacuolar myopathy associated with chloroquine, lupus erythematosus and thymoma. J Neurol Sci 1977;34: 315-328.

41. Wasay M, Wolfe GI, Herrold JM, et al. Chloroquine myopathy and neuropathy with elevated CSF protein. Neurology 1998;51:1226-1227.

42. Estes ML, Ewing-Wilson D, Chou SM, et al. Chloroquine neuromyotoxicity: clinical and pathological perspective. Am J Med 1987;82:447-455.

43. Doughty CT, Amato AA. Toxic myopathies. Continuum 2019;25:1712-1731.

44. Varan O, Kucuk H, Tufan A. Myasthenia gravis due to hydroxychloroquine. Reumatismo 2015;67:849.

45. Jallouli M, Saadoun D, Eymard B, et al. The association of systemic lupus eryth ematosus and myasthenia gravis: a series of 17 cases, with a special focus on hydroxychloroquine use and a review of the literature. J Neurol 2011;259:1290-1297.

46. Arabi YM, Harthi A, Hussein J, et al. Severe neurologic syndrome associated with Middle East respiratory syndrome corona virus (MERS-CoV) infection. 2015;43: 495-501.

47. Kwong JC, Vasa PP, Campitelli MA, et al. Risk of Guillain-Barré syndrome after seasonal influenza vaccination and influenza health-care encounters: a self-controlled study. Lancet Infect Dis 2013;13:769-776.

48. Galeotti F, Massari M, D’Alessandro R,. Risk of Guillain-Barré syndrome after 20102011 influenza vaccination. Eur J Epidemiol 2013;28:433-444.

49. Grave C, Boucheron P, Rudant J, et al. Seasonal influenza vaccine and Guillain-Barré syndrome: a self-controlled case series study. Neurology Epub 2020 Feb 25.
50. Dodd CN, Romio SA, Black S, et al. International collaboration to assess the risk of Guillain Barré syndrome following influenza A (H1N1) 2009 monovalent vaccines. Vaccine 2013;31:4448-4458.

51. De Wals P, Deceuninck G, Toth E, et al. Risk of Guillain-Barré syndrome following H1N1 influenza vaccination in Quebec. JAMA 2012;308:175-181.

52. Crawford NW, Cheng A, Andrews N, et al. Guillain-Barré syndrome following pandemic (H1N1) 2009 influenza A immunisation in Victoria: a self-controlled case series. Med J Aust 2012;197:574-578.

53. Polakowski LL, Sandhu SK, Martin DB, et al. Chart-confirmed Guillain-Barre syndrome after $2009 \mathrm{H} 1 \mathrm{~N} 1$ influenza vaccination among the Medicare population, 20092010. Am J Epidemiol 2013;178:962-973.

54. Salmon DA, Proschan M, Forshee R, et al. Association between Guillain-Barré syndrome and influenza A (H1N1) 2009 monovalent inactivated vaccines in the USA: a meta-analysis. Lancet 2013;381:1461-1468.

55. Greene SK, Rett MD, Vellozzi C, et al. Guillain-Barré syndrome, influenza vaccination, and antecedent respiratory and Gastrointestinal infections: a case-centered analysis in the Vaccine Safety Datalink, 2009-2011. PLoS One 2013;8:e67185.

56. Greene SK, Rett M, Weintraub ES, et al. Risk of confirmed Guillain-Barre syndrome following receipt of monovalent inactivated influenza A (H1N1) and seasonal influenza vaccines in the Vaccine Safety Datalink Project, 2009-2010. Am J Epidemiol 2012;175:1100-1109.

57. AANEM COVID website [Internet]. 2020. Available at: aanem.org/Practice/ COVID-19-Guidance. Accessed April 9, 2020.

58. American Physical Therapy AssociationAvailable at: apta.org/telehealth/. Accessed April 9, 2020.

59. Numotion [Internet]. 2020. Available at: numotion.com/medical-professionals/remote-evals-deliveries-service. Accessed April 9, 2020

60. Schwamm LH, Chumbler N, Brown E, et al. Recommendations for the implementation of telehealth in cardiovascular and stroke care: a policy statement from the American Heart Association. Circulation 2017;135:e24-e44.

61. Keesara S, Jonas A, Schulman K. Covid-19 and health care's digital revolution. N Engl J Med Epub 2020 Apr 2

62. Paganoni S, Simmons Z. Telemedicine to innovate amyotrophic lateral sclerosis multidisciplinary care: the time has come. Muscle Nerve 2018;59:3-5.

63. Govindarajan R, Anderson ER, Hesselbrock RR, et al. Developing an outline for teleneurology curriculum. Neurology 2017;89:951-959.

64. Afshari M, Witek NP, Galifianakis NB. Education Research: an experiential outpatient teleneurology curriculum for residents. Neurology 2019;93:170-175.

65. Donelan K, Barreto E, Sossong S, et al. Patient and clinician experiences with telehealth for patient follow-up care. Am J Manag Care 2019;25:40-44.

66. Cohen BH, Busis NA, Ciccarelli L. Coding in the world of COVID-19: non-face-toface evaluation and management care. Continuum 2020;26:1-25. 


\title{
Neurology
}

\author{
COVID-19 and neuromuscular disorders \\ Amanda C. Guidon and Anthony A. Amato \\ Neurology 2020;94;959-969 Published Online before print April 13, 2020 \\ DOI 10.1212/WNL.0000000000009566
}

This information is current as of April 13, 2020

\section{Updated Information \& Services}

\section{References}

Citations

Subspecialty Collections

Permissions \& Licensing

Reprints including high resolution figures, can be found at: http://n.neurology.org/content/94/22/959.full

This article cites 51 articles, 6 of which you can access for free at: http://n.neurology.org/content/94/22/959.full\#ref-list-1

This article has been cited by 8 HighWire-hosted articles: http://n.neurology.org/content/94/22/959.full\#\#otherarticles

This article, along with others on similar topics, appears in the following collection(s):

All Immunology

http://n.neurology.org/cgi/collection/all_immunology

All Neuromuscular Disease

http://n.neurology.org/cgi/collection/all_neuromuscular_disease All Practice Management

http://n.neurology.org/cgi/collection/all_practice_management

Information about reproducing this article in parts (figures,tables) or in its entirety can be found online at:

http://www.neurology.org/about/about_the_journal\#permissions

Information about ordering reprints can be found online:

http://n.neurology.org/subscribers/advertise

Neurology ${ }^{\circledR}$ is the official journal of the American Academy of Neurology. Published continuously since 1951, it is now a weekly with 48 issues per year. Copyright (O) 2020 American Academy of Neurology. All rights reserved. Print ISSN: 0028-3878. Online ISSN: 1526-632X.

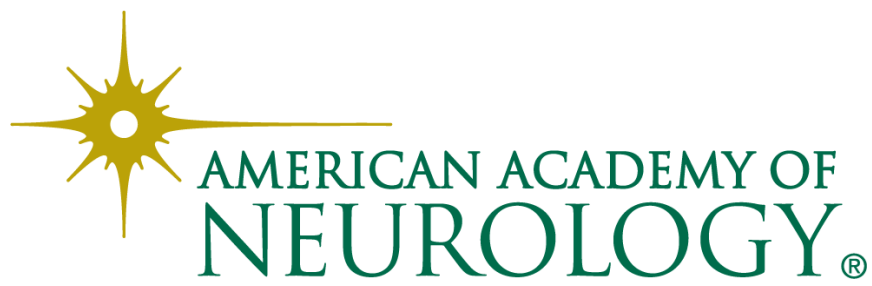

